\title{
RUBIDIUM-RICH FELDSPARS AND ASSOCIATED MINERALS FROM THE LUOLAMÄKI PEGMATITE, SOMERO, FINLAND
}

\author{
DAVID K. TEERTSTRA, PETR ČERNÝ and FRANK C. HAWTHORNE
}

\begin{abstract}
TEERTSTRA, D.K., ČERNÝ, P. and HAWTHORNE, F.C. 1998. Rubidium-rich feldspars and associated minerals from the Luolamäki pegmatite, Somero, Finland. Bulletin of the Geological Society of Finland 70, Parts 1-2, 43-49.

Rubidium feldspar occurs near the core zone of the highly fractionated petalite-subtype Luolamäki granitic pegmatite in intimate intergrowth with other feldspars which are part of a characteristic sequence of alteration of pollucite. Pods of pollucite are cut by 5-20 cm-wide veins of albite, petalite, non-perthitic microcline, lepidolite and quartz, by thinner veins of fine-grained micas and spodumene, and are replaced by metasomatic adularia. Grains of rubidium feldspar occur as a potentially ordered phase in the vein microcline in association with earlier-exsolved albite, and also as late thin $(<5 \mu \mathrm{m})$ veinlets. Rubidium feldspar also occurs as a potentially disordered phase which crystallized along with metasomatic adularia. Both generations of $(\mathrm{Rb}, \mathrm{K})$-feldspar have a similar compositional range, close to the join $\mathrm{KAlSi}_{3} \mathrm{O}_{8}-\mathrm{RbAlSi}_{3} \mathrm{O}_{8}$, typically with up to $\sim 21$ wt. \% $\mathrm{Rb}_{2} \mathrm{O}(\sim 70 \mathrm{~mol} . \% \mathrm{Rbf})$ and with minor $\mathrm{Cs}$, but neglible $\mathrm{Na}, \mathrm{Ca}$, $\mathrm{Fe}$ or P. Extreme compositions have 26.0 wt. $\% \mathrm{Rb}_{2} \mathrm{O}(89.0 \mathrm{~mol} \% \mathrm{Rbf})$ and 1.26 wt. $\% \mathrm{Cs}_{2} \mathrm{O}$ (2.8 mol.\% Csf). The diffuse compositional gradients from microcline to rubicline are consistent with a solid-state exsolution origin, followed by fluid-assisted textural coarsening which generates distinct phase boundaries. In contrast, metasomatic adularian $(\mathrm{Rb}, \mathrm{K})$-feldspar was precipitated at low temperature $\left(250-150^{\circ} \mathrm{C}\right)$ and fine-scale zoning with variable $\mathrm{K} / \mathrm{Rb}$ is preserved as a growth feature.
\end{abstract}

Key words: pegmatite, feldspar group, rubidium, K-feldspar, rubicline, microcline, adularia, Proterozoic, Luolamäki, Finland

David K. Teertstra, Petr Č́rný and Frank C. Hawthorne: Department of Geological Sciences, University of Manitoba, Winnipeg, Manitoba, Canada R3T 2N2.

E-mail:p_cerny@umanitoba.ca

\section{INTRODUCTION}

The rubidium-dominant feldspars are a recent addition to the feldspar group and are the first known mineral(s) with rubidium as an essential constituent. Rubicline has been characterized as the $\mathrm{Rb}>\mathrm{K}$ analogue of microcline (Teertstra et al. 1998a), and a natural (Al,Si)-disordered species (analogous to synthetic rubidian high sanidine) also probably exists. Description of rubicline from the type locality, a highly fractionated granitic pegmatite at San Piero in Campo, Elba, Italy, was largely restricted to its characterization as a new species. A fine-grained $\mathrm{Rb}>\mathrm{K}$ feldspar of unkno- 
wn structural state was briefly described from a pegmatite in the Kola Peninsula (Teertstra et al. 1997), but genetic interpretation was limited due to the small quantity of material available. A detailed petrologic description of rubidium feldspar and the associated minerals is required, to characterize their mode of formation. The Luolamäki pegmatite affords sufficient material, in which the rubidium feldspars are relatively common, for such a description and interpretation.

The Luolamäki pegmatite is a member of the Somero-Tammela pegmatite field, located in SW Finland about $100 \mathrm{~km}$ NW of Helsinki. The pegmatite belongs to the petalite subtype of complex pegmatites, with negligible quantities of lithian micas and no primary spodumene. The upper half of the pegmatite is albite-rich, and the lower half is K-feldspar-rich. Petalite, quartz and pollucite occur in the core zone, cut by veins of cleavelandite, quartz, schorl and muscovite (Vesasalo 1959, Neuvonen \& Vesasalo 1960, Teertstra et al. 1993). Bulk compositions of microcline-perthite have 1.51 wt.\% $\mathrm{Rb}_{2} \mathrm{O}$ (Neuvonen \& Vesasalo 1960); however, the K-feldspar most enriched in rubidium occurs near the core of the pegmatite in close association with pollucite. Here, we describe $(\mathrm{Rb}, \mathrm{K})$-feldspars found as part of a characteristic sequence of alteration of the Luolamäki pollucite, examined in detail by Teertstra et al. (1993). Study of the alteration sequences of pollucite has greatly constrained the possible physical and chemical conditions under which the associated rubidiumrich feldspars may form (Teertstra \& Č̌erný 1995).

\section{EXPERIMENTAL}

Mineral compositions were measured using wavelength-dispersion (WDS) analysis on a CAMECA SX-50 electron microprobe (EMP) operating at 15 $\mathrm{kV}$ and $20 \mathrm{nA}$ with a beam diameter of $5 \mu \mathrm{m}$. Using these conditions, gain or loss of alkali elements from the EMP-analysed volume is negligible. Data were reduced using the PAP procedure of Pouchou and Pichoir (1985). Major elements were measured using a glass of $\mathrm{Rb}_{2} \mathrm{ZnSi}_{5} \mathrm{O}_{12}$ stoichiometry $(\mathrm{Rb} L \alpha)$ and gem sanidine from
Volkesfeld, Eifel, Germany (K $K \alpha, \mathrm{Al} K \alpha$, Si $K \alpha$ ). The procedure of Teertstra et al. (1997) was used to accurately measure the composition of the sanidine and to provide conformity with the ideal feldspar stoichiometry. Minor elements were measured using albite ( $\mathrm{Na} K \alpha$ ), pollucite (Cs $L \alpha$ ), fayalite $(\mathrm{Fe} K \alpha)$, barite $(\mathrm{Ba} L \beta), \mathrm{SrTiO}_{3}(\mathrm{Sr} L \alpha)$ and $\mathrm{VP}_{2} \mathrm{O}_{5}(\mathrm{P} K \alpha)$. The elements $\mathrm{Mg}$, Ti, F, Mn, $\mathrm{Ga}, \mathrm{Ca}$ and $\mathrm{Pb}$ were sought but not detected in any generation of feldspar; limits of detection and additional experimental details are provided in Teertstra et al. (1997).

Feldspar formulae were calculated on the basis of eight atoms of oxygen per formula unit (apfu). Monovalent and divalent cations were assigned to the $M$-site and higher-valency cations to the $T$-site of the general formula $M T_{4} \mathrm{O}_{8}$. The compositions of phosphorus-bearing and phosphorusfree feldspars were compared via the berlinite (AlP) $\mathrm{Si}_{-2}$ substitution (e.g., Kontak et al. 1996), using $\mathrm{TO}_{2}{ }^{-}=(\mathrm{Al}-\mathrm{P})$ for the negative charge of the framework and $\mathrm{Si}+2 \mathrm{P}$, where $\mathrm{P}$ equals $\mathrm{P}$ plus $\mathrm{Al}-$ equivalent of $\mathrm{P}$. Compositional vectors thereby directly correspond to the plagioclase-like $\left(M^{2+} \mathrm{Al}\right)\left(M^{1+} \mathrm{Si}\right)_{-1}$ substitution, and to the "excess"silicon $\square \mathrm{Si}_{4} \mathrm{O}_{8}$ substitution (i.e., $\square \mathrm{Si}(\mathrm{KAl})_{-1}$ ). Comparison of charge of the framework with $M$ cation charge, $\mathrm{M}^{+}=$(monovalent $+2 \times$ divalent $)$ cations, gives a trend for incorporation of lightelement $M$-cations which cannot be directly measured by the electron microprobe.

In the following text, the term $(\mathrm{K}, \mathrm{Rb})$-feldspar is used for $\mathrm{K}$-dominant compositions, and ( $\mathrm{Rb}, \mathrm{K})$ feldspar for Rb-dominant compositions; (K-Rb)feldspars designates members of the substitutional series. Rbf and Csf signify the end-member components of ideal rubidium feldspar and cesium feldspar, respectively.

\section{THE RUBIDIUM-RICH FELDSPARS}

The rubidium-rich feldspars occur in intimate intergrowth with two generations of K-rich feldspars which form part of the sequence of alteration of pollucite. Pods of pollucite near the core of the pegmatite are largely monomineralic, but contain 
scattered grains of quartz, apatite and K-feldspar. Pollucite is cut by $5-20 \mathrm{~cm}$-wide veins of albite, petalite, non-perthitic microcline (+ lepidolite), lepidolite (+ quartz) and quartz, and by later 1-2 mm-wide veins of muscovite + quartz + apatite, followed by thinner $(<0.5 \mathrm{~mm})$ veinlets of finegrained muscovite + spodumene. Aggregates of fine-grained adularian (K-Rb)-feldspar overgrow the microcline and mica veins, and metasomatically replace microcline veins and pollucite. Minor cation exchange and leaching of pollucite is followed by local replacement by clay minerals.

The vein microcline is tartan-twinned and forms a vein network with uniform optical orientation throughout the pollucite. The microcline has a patchy compositional pattern, particularly in microporous areas, with wt.\% ranges of 1.32-5.64 $\mathrm{Rb}_{2} \mathrm{O}, 0.09-0.29 \mathrm{Na}_{2} \mathrm{O}, 0.12-0.32 \mathrm{Cs}_{2} \mathrm{O}$, and 0.13$0.62 \mathrm{P}_{2} \mathrm{O}_{5}$. The variation in $\mathrm{Rb}_{2} \mathrm{O}$ corresponds to 4-17 mol.\% Rbf. Areas of minimal porosity tend to have higher concentrations of $\mathrm{Rb}, \mathrm{Na}$ and $\mathrm{P}$, and a more homogeneous composition than areas which have high pore density (Fig. 1A, 1C). $(\mathrm{Rb}, \mathrm{K})$-feldspar is associated with irregular veins of patch albite which are oriented approximately parallel to planes of microcline cleavage, and thin veinlets of $(\mathrm{Rb}, \mathrm{K})$-feldspar crosscut this assemblage (Fig. 1A). (Rb,K)-feldspar adjacent to grains of lepidolite commonly shows a gradation of $\mathrm{K} /$ $\mathrm{Rb}$ from the host microcline (Fig. 1B). Small round blebs of $(\mathrm{Rb}, \mathrm{K})$-feldspar also occur fully embedded in the microcline (Fig. 1A, 1C, Table 1). Microcline is otherwise commonly replaced by adularia with composition of end-member K-feldspar (Fig. 1C). The assemblage (Rb,K)-feldspar + quartz occurs within some of the irregular and narrow veins of microcline in pollucite (Fig. 1D). Compositions of the ( $\mathrm{Rb}, \mathrm{K})$-feldspar in microcline are independent of the association with albite or lepidolite, but they range up to approximately 20.9 wt. $\% \mathrm{Rb}_{2} \mathrm{O}$ (69 mol.\% Rbf) and 1.3 wt. $\% \mathrm{Cs}_{2} \mathrm{O}$ (3 mol.\% Csf). The Rb-richest feldspar ( $89 \mathrm{~mol} \%$ Rbf; Table 1, No. 6) occurs as a small grain between grains of lepidolite, isolated from the microcline.

Adularian (K,Rb)-feldspar replacing pollucite contains 2.98 wt. $\% \mathrm{Rb}_{2} \mathrm{O}$ in its bulk composition
(Neuvonen \& Vesasalo 1960). However, it is actually zoned with variable $\mathrm{K} / \mathrm{Rb}$, and contains abundant inclusions of cookeite, with minor apatite and small ( $<1 \mu \mathrm{m}$ diameter) grains of pollucite (Fig. 1E). Adularia locally overgrows microcline in parallel orientation, indicating that the microcline substrate provided a surface for easy epitactic nucleation and subsequent growth. Late overgrowths of adularia tend to be extremely microporous and are associated with leaching and analcimization of pollucite. Most of the adularia has end-member composition of $\mathrm{KAlSi}_{3} \mathrm{O}_{8}$, but local gradations of $(\mathrm{K}, \mathrm{Rb})$ - to $(\mathrm{Rb}, \mathrm{K})$-feldspar are relatively common (Fig. 1F). The adularian ( $\mathrm{Rb}$ $\mathrm{K}$ )-feldspar has a similar compositional range and upper compositional limit as the (Rb-K)-feldspar in microcline, with up to 20.95 wt. $\% \mathrm{Rb}_{2} \mathrm{O}(70$ mol.\% Rbf). Representative compositions are given in Table 1.

Mean values for (Al-P) of 0.995(15) apfu and $M$-cation charge of $0.987(16) p f u$ suggest on average 1 at.\% light-element substitution, with individual values up to 4 at.\% (Fig. 2A). Compositional trends indicate widespread substitution of $\square \mathrm{Si}_{4} \mathrm{O}_{8}$, with individual values attaining $4 \mathrm{~mol} . \%$ $\square \mathrm{Si}_{4} \mathrm{O}_{8}$ substitution (Fig. 2B). Mean values for $(\mathrm{Si}+2 \mathrm{P})$ of $3.007(14)$ and mean values of $\Sigma T$ of 4.002(4) indicate good overall agreement with the feldspar formula, taking into account the $\square \mathrm{Si}_{4} \mathrm{O}_{8}$ and berlinite substitutions. Sums of $(\mathrm{K}+\mathrm{Rb})$ are slightly lower than the ideal 1.0 apfu line because of minor $\square$, Cs and light-element substitution (Fig. $2 \mathrm{C}$ ); the mean $\Sigma M$ value is $0.984(15) a p f u$. Substitution of $\mathrm{Cs}$ increases irregularly with $\mathrm{Rb}$ to a maximum of approximately 0.03 apfu (3 mol.\% Csf), corresponding to 1.5 wt. $\% \mathrm{Cs}_{2} \mathrm{O}$ (Fig. 2D).

\section{DISCUSSION}

The conditions of formation of the rubidium feldspars are broadly constrained. The range of temperature of consolidation of highly fractionated peraluminous melts of granitic bulk composition, rich in $\mathrm{H}_{2} \mathrm{O}, \mathrm{B}, \mathrm{F}, \mathrm{Li}, \mathrm{Rb}$ and $\mathrm{Cs}$, is estimated to be about $650-450^{\circ} \mathrm{C}$ at $4-2 \mathrm{kbar}$ (London 1986, Chakoumakos \& Lumpkin 1990). In the petalite- 

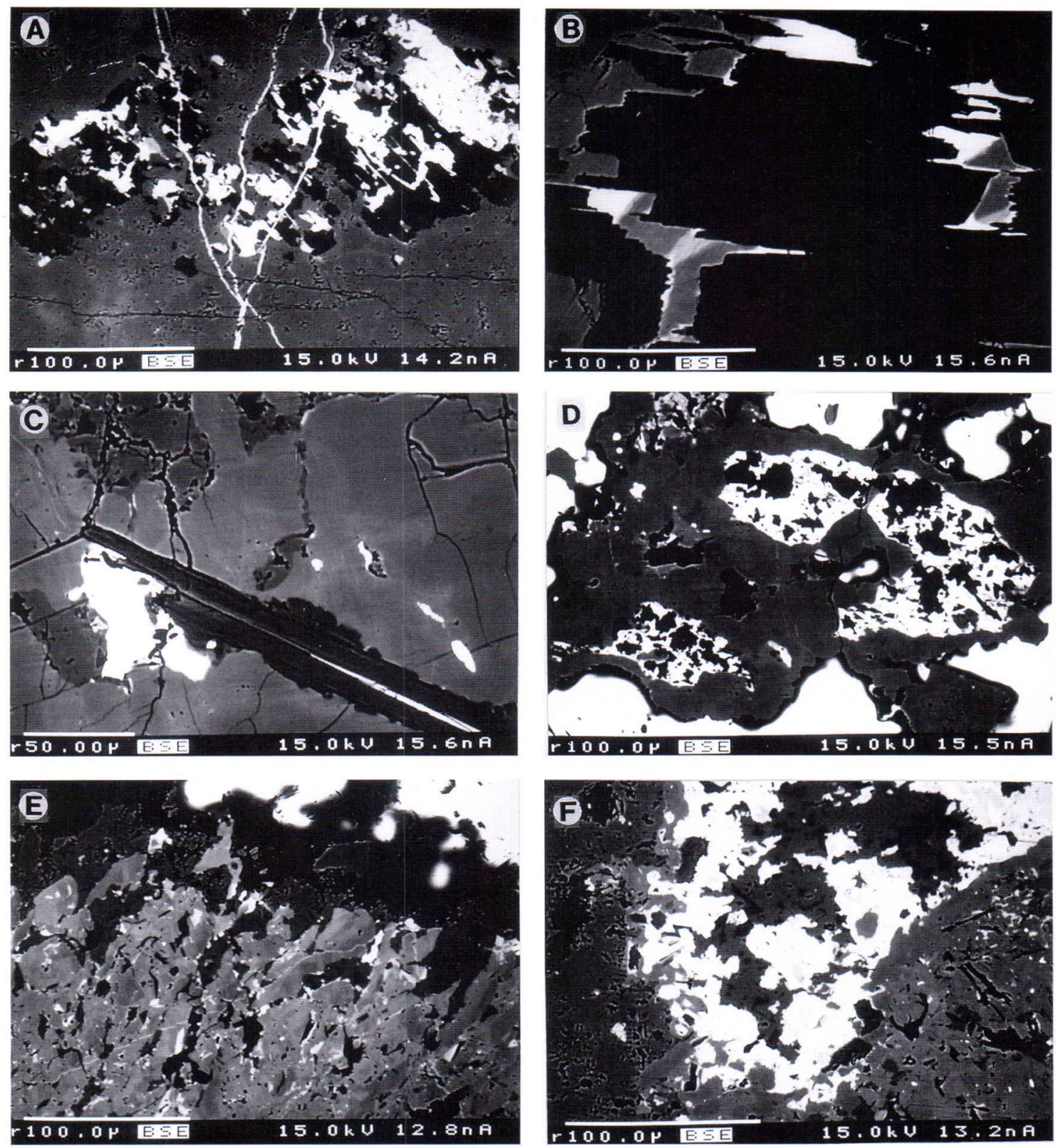

Fig. 1. BSE images of feldspars and associated minerals in non-perthitic vein microcline $(A$ to $C)$ and in aggregates metasomatic after pollucite ( $D$ to $F$ ): (A) microporous vein microline with a patchy distribution of Rb (variable grey) contains patch albite (black) and (Rb,K)-feldspar (white), cut by veinlets of $(R b, K)$-feldspar; (B) (Rb,K)feldspar (white) between grains of lepidolite (black), showing a compositional gradient from microcline (grey); (C) laths of lepidolite (with interlayer apatite - white) in microcline (grey) are associated with (Rb,K)-feldspar (white) and locally replaced by Rb-poor K-feldspar (dark grey); (D) blebs of Rb-rich feldspar (white) $+q u a r t z$ (black) in Rb-bearing microcline (grey), surrounded by pollucite (white); (E) late adularian (K-Rb)-feldspar (grey to white) + cookeite (black) has a rim of K-feldspar (dark grey) which is closely associated with analcimization of pollucite (upper right, black to white); $(F)$ adularian $(R b, K)$-feldspar (white) + cookeite (black) and porous $R b$-poor K-feldspar (variable grey). 
Table 1. Representative compositions of $(K-R b)$-feldspar.

\begin{tabular}{|c|c|c|c|c|c|c|c|c|}
\hline oxide & 1 & 2 & 3 & 4 & 5 & 6 & 7 & 8 \\
\hline $\mathrm{SiO}_{2}$ & 63.66 & 58.06 & 63.46 & 58.05 & 60.85 & 55.98 & 63.98 & 58.05 \\
\hline $\mathrm{Al}_{2} \mathrm{O}_{3}$ & 18.13 & 16.42 & 17.68 & 16.02 & 17.03 & 16.10 & 18.64 & 15.97 \\
\hline $\mathrm{P}_{2} \mathrm{O}_{5}$ & 0.20 & 0.02 & 0.00 & 0.00 & 0.00 & 0.06 & 0.05 & 0.19 \\
\hline $\mathrm{Na}_{2} \mathrm{O}$ & 0.09 & 0.00 & 0.03 & 0.00 & 0.02 & 0.00 & 0.08 & 0.00 \\
\hline $\mathrm{K}_{2} \mathrm{O}$ & 14.84 & 5.10 & 13.43 & 3.92 & 8.94 & 1.64 & 16.27 & 4.84 \\
\hline $\mathrm{Rb}_{2} \mathrm{O}$ & 2.77 & 19.55 & 4.53 & 20.55 & 12.43 & 26.02 & 0.00 & 18.25 \\
\hline $\mathrm{Cs}_{2} \mathrm{O}$ & 0.23 & 0.66 & 0.08 & 1.05 & 0.49 & 0.60 & 0.02 & 1.26 \\
\hline $\mathrm{SrO}$ & 0.05 & 0.09 & 0.00 & 0.05 & 0.09 & 0.06 & 0.00 & 0.11 \\
\hline $\mathrm{BaO}$ & 0.00 & 0.14 & 0.10 & 0.08 & 0.05 & 0.06 & 0.31 & 0.01 \\
\hline \multirow[t]{2}{*}{ sum } & 99.97 & 100.04 & 99.31 & 99.72 & 99.90 & 100.52 & 99.32 & 98.68 \\
\hline & \multicolumn{8}{|c|}{ Atomic contents based on 8 atoms of oxygen } \\
\hline $\mathrm{Si}$ & 2.991 & 2.997 & 3.017 & 3.019 & 3.010 & 2.982 & 2.982 & 3.009 \\
\hline $\mathrm{Al}$ & 1.004 & 0.999 & 0.990 & 0.982 & 0.993 & 1.011 & 1.024 & 0.976 \\
\hline $\mathrm{P}$ & 0.008 & 0.001 & 0.000 & 0.000 & 0.000 & 0.003 & 0.002 & 0.009 \\
\hline $\mathrm{Na}$ & 0.008 & 0.000 & 0.003 & 0.000 & 0.002 & 0.000 & 0.007 & 0.000 \\
\hline $\mathrm{K}$ & 0.889 & 0.336 & 0.814 & 0.260 & 0.564 & 0.112 & 0.967 & 0.320 \\
\hline $\mathrm{Rb}$ & 0.084 & 0.649 & 0.138 & 0.687 & 0.395 & 0.891 & 0.000 & 0.608 \\
\hline Cs & 0.005 & 0.014 & 0.002 & 0.023 & 0.010 & 0.014 & 0.000 & 0.028 \\
\hline $\mathrm{Sr}$ & 0.001 & 0.003 & 0.000 & 0.002 & 0.003 & 0.002 & 0.000 & 0.003 \\
\hline $\mathrm{Ba}$ & 0.000 & 0.003 & 0.002 & 0.002 & 0.001 & 0.001 & 0.006 & 0.000 \\
\hline$\Sigma M$ & 0.987 & 1.004 & 0.959 & 0.974 & 0.975 & 1.019 & 0.981 & 0.974 \\
\hline$M^{+}$ & 0.989 & 1.010 & 0.961 & 0.977 & 0.979 & 1.022 & 0.987 & 0.993 \\
\hline$T \mathrm{O}_{2^{-}}$ & 0.996 & 0.999 & 0.990 & 0.982 & 0.993 & 1.010 & 1.023 & 0.968 \\
\hline$\Sigma T$ & 4.002 & 3.997 & 4.007 & 4.001 & 4.004 & 3.997 & 4.009 & 3.994 \\
\hline
\end{tabular}

1 and 2. Microcline vein in pollucite and coexisting exsolved bleb of $(\mathrm{Rb}, \mathrm{K})$-feldspar, respectively.

3 and 4 . A second pair of microcline $+(\mathrm{Rb}, \mathrm{K})$-feldspar.

5. $\mathrm{Rb}$-rich feldspar associated with late albite.

6. $(\mathrm{Rb}, \mathrm{K})$-feldspar associated with lepidolite.

7. and 8 . Adularia $+(\mathrm{Rb}, \mathrm{K})$-feldspar replacing pollucite.

bearing Luolamäki pegmatite, free of primary spodumene, the pressure during magmatic crystallization must have been below $\sim 2.6 \mathrm{kbar}$ ( $c f$. London 1984). Blocky (K,Na,Rb)-feldspar, associated with hydrous sodian pollucite in late-crystallizing core-margin and core zones, probably crystallized near the lower end of the above temperature range. Pollucite is a near-solidus phase, as documented from its paragenetic relationships (summarized in Č́rný 1982) and by experimental work (Henderson \& Manning 1984, London et al. 1998). Veining of pollucite bodies by Na-poor, non-perthitic microcline proceeded in the subsolidus regime, in the stability field of microcline $\left(\mathrm{T}<450^{\circ} \mathrm{C}\right.$; Teertstra et al. 1998a). Replacement of pollucite by adularia likely took place in a temperature range as low as $250-150^{\circ} \mathrm{C}$ (Teertstra \& Č́ný 1995).
If potassium feldspars contain variable concentrations of rubidium, then multiple generations of $\mathrm{K}$-feldspar are revealed using back-scattered electron (BSE) imaging, a technique which is sensitive to variation in mean atomic number. Most of the fine-scale compositional, textural and paragenetic relations of K-feldspar are otherwise obscure in hand specimen and in thin section. At Luolamäki, (Rb,K)-feldspars occur mainly in two associations: (1) in microcline veins which crosscut pollucite, and (2) in late-stage metasomatic replacement of pollucite and microcline by adularia.

(1) Rubidium feldspar in the microcline veins usually occurs at grain boundaries of included minerals such as albite or lepidolite; most likely, these provided easy sites for nucleation. Diffuse 

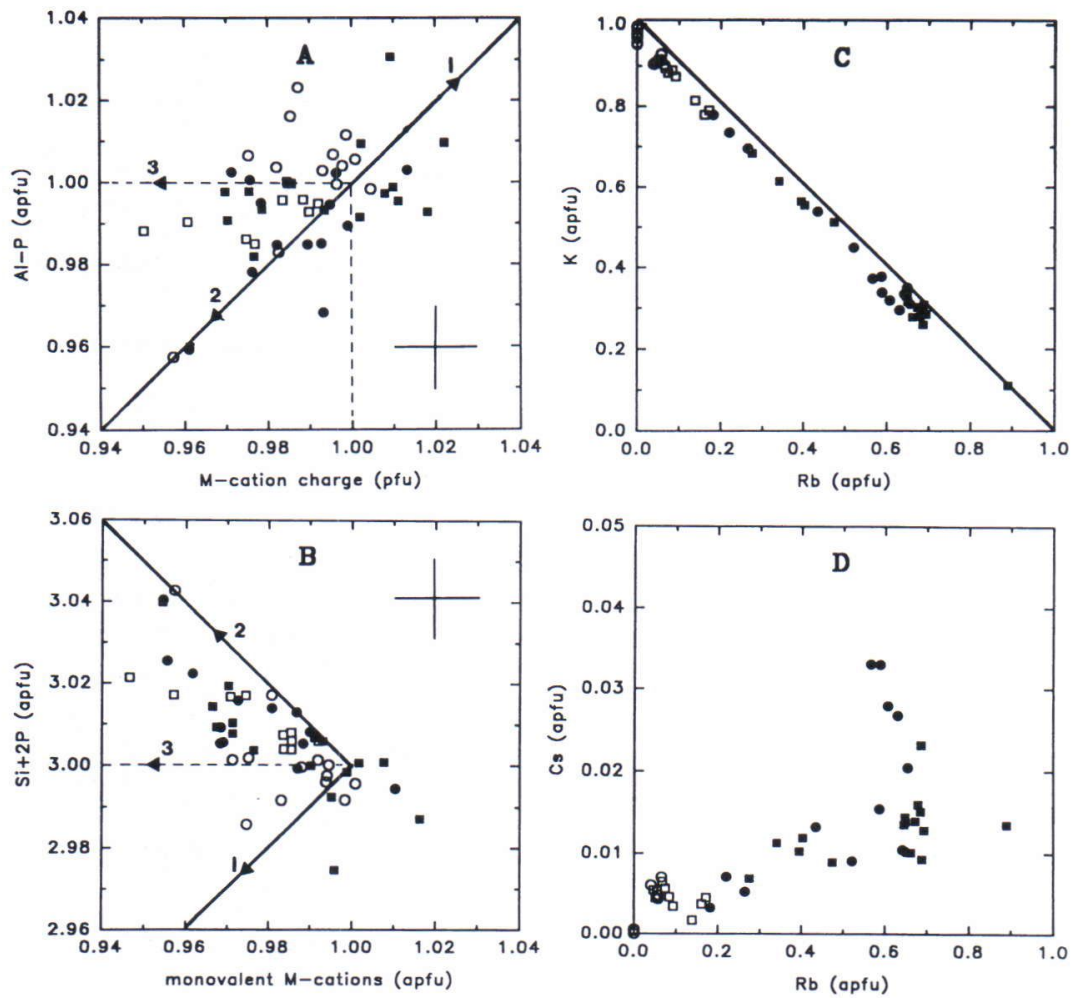

Fig. 2. Element variation in ( $K$-Rb)-feldspars: (A) (Al-P) vs. M-cation charge with a 1:1 trend line; $(B)(S i+2 P)$ vs. sum of monovalent $M$-cations; $(C) K v s$. Rb, with a line indicating $\Sigma M=1 ;(D) C s$ vs. Rb. Symbols: vein microcline in pollucite $\square$ and associated (Rb,K)-feldspar $\mathbf{\square}$; late adularia $O$ and associated (Rb,K)-feldspar $\bullet$.

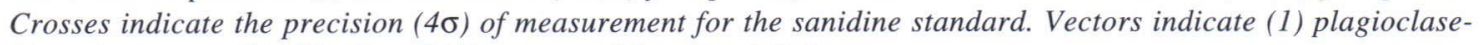
like substitution, (2) $\square \mathrm{Si}_{4} \mathrm{O}_{8}$ and (3) apparent $\mathrm{M}$-cation deficiency.

compositional gradients from microcline to $(\mathrm{Rb}>\mathrm{K})$-feldspar are consistent with a mechanism of solid-state alkali diffusion for the exsolution of rubidium-dominant feldspar from a $(\mathrm{K}, \mathrm{Na}, \mathrm{Rb})$ feldspar precursor. This mechanism was documented on material from Elba: at the scale of EMP BSE imaging, Elban rubicline shows sharp apparent phase boundaries with host microcline, yet high-resolution transmission electron microscopy shows that the structure is continuous from microcline to rubicline (Teertstra et al. 1998a). If the (Al,Si)-ordered framework of Luolamäki microcline is continuous with that of the associated ( $\mathrm{Rb}>\mathrm{K}$ )-feldspar, this Rb-dominant feldspar would also be triclinic and should properly be named rubicline; however, we do not have experimental proof. The cation diffusion is locally incomplete in the Luolamäki material, producing diffuse compositional gradients; any additional textural coarsening producing sharp phase boundaries is probably fluid-assisted.

(2) Highly porous adularian (K-Rb)-feldspar crystallized with cookeite in association with analcimization of pollucite. This constrains the temperature range of formation to as low as 250$150^{\circ} \mathrm{C}$ (Teertstra \& Černý 1995). Variation in K/ $\mathrm{Rb}$ is observed on a fine scale, and this zoning probably has been preserved as a feature of growth rather than of later reaction, at a temperature too low for significant alkali diffusion (Giletti 1994). The adularia is untwinned and most likely is monoclinic and (Al,Si)-disordered, as is typical of many occurrences of structurally metastable adularia, which crystallizes at a temperature too low 
for subsequent ordering, even in the presence of abundant fluid (e.g, Teertstra et al. 1998b). If this is the case, the $\mathrm{Rb}$-dominant parts of the adularia clusters would correspond to a yet-unnamed $\mathrm{Rb}$ analog of sanidine (currently examined on relatively better material from other localities). The epitactic overgrowths of adularia on microcline also are significant, because a suitable substrate promotes nucleation at low temperature. Rubidium for the $(\mathrm{Rb}>\mathrm{K})$-feldspar was apparently locally derived, by reaction of metasomatic fluid with rubidium-bearing precursors, microcline and pollucite.

ACKNOWLEDGEMENTS: This research was supported by NSERC Research and Major Installati-

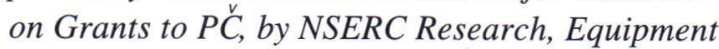
and Infrastructure Grants to FCH and by a University of Manitoba Duff Roblin Fellowship to DKT. Thanks go to K.J. Neuvonen for some of the pollucite + feldspar samples, to C.M.B. Henderson for the Rb standard, to $H$. Wondratschek for the Eifel sanidine, and to two anonymous reviewers for their comments on the manuscript.

\section{REFERENCES}

Černý, P. 1982. Mineralogy of rubidium and cesium. In: Černý, P. (ed.) Granitic Pegmatites in Science and Industry. Mineralogical Association of Canada, Short Course Handbook 8, 149-161.

Chakoumakos, B.C. \& Lumpkin, G.R. 1990. Pressure-temperature constraints on the crystallization of the Harding pegmatite, Taos County, New Mexico. Canadian Mineralogist 28, 287-298.

Giletti, B.J. 1994. Isotopic equilibrium/disequilibrium and diffusion kinetics in feldspars. In: Parsons, I. (ed.) Feldspars and their Reactions. NATO ASI Series C, Mathematical and Physical Sciences. Boston: Reidel Publishing Co., 351-382.
Henderson, C.M.B. \& Manning, D.A.C. 1984. The effect of Cs on phase relations in the granite system: stability of pollucite. National Environmental Research Council, Program of Experimental Petrology 25, 41-42.

Kontak, D.J., Martin, R.F. \& Richard, L. 1996. Patterns of phosphorus enrichment in alkali feldspar, South Mountain Batholith, Nova Scotia, Canada. European Journal of Mineralogy 8, 805-824.

London, D. 1984. Experimental phase equilibria in the system $\mathrm{LiAlSiO}_{4}-\mathrm{SiO}_{2}-\mathrm{H}_{2} \mathrm{O}$ : a petrogenetic grid for lithiumrich pegmatites. American Mineralogist 69, 995-1004.

London, D. 1986. Magmatic-hydrothermal transition in the Tanco rare-element pegmatite: Evidence from fluid inclusions and phase-equilibria experiments. American Mineralogist 71, 376-395.

London, D., Morgan, G.B.VI and Icenhower, J. 1998. Stability and solubility of pollucite in the granite system at $200 \mathrm{Mpa} \mathrm{H}_{2} \mathrm{O}$. Canadian Mineralogist 36, 497-510.

Neuvonen, K.J. \& Vesasalo, A. 1960. Pollucite from Luolamäki, Somero, Finland. Bulletin de la Commission géologique de Finlande 188, 133-148.

Pouchou, J.L. \& Pichoir, F. 1985. "PAP" (phi-rho-Z) procedure for improved quantitative microanalysis. In: Armstrong, J.T. (ed.) Microbeam Analysis. San Francisco, California: San Francisco Press, 104-106.

Teertstra, D.K. \& Černý, P. 1995. First natural occurrences of end-member pollucite: A product of low-temperature reequilibration. European Journal of Mineralogy 7, 1137-1148.

Teertstra, D.K., Černý, P. \& Hawthorne, F.C. 1997. Rubidium-rich feldspars in a granitic pegmatite from the Kola Peninsula, Russia. Canadian Mineralogist 35, 1277-1281.

Teertstra, D.K., Črný, P., Hawthorne, F.C., Pier, J., Wang, Lu-Min \& Ewing, R.C. 1998a. Rubicline, a new feldspar from San Piero in Campo, Elba, Italy. American Mineralogist 83, 1335-1339.

Teertstra, D.K., Hawthorne, F.C. \& Černý, P. 1998b. Identification of normal and anomalous compositions of minerals by electron-microprobe analysis: K-rich feldspar as a case study. Canadian Mineralogist 36, 87-95.

Teertstra, D.K., Lahti, S.I., Alviola, R. \& Černý, P. 1993. Pollucite and its alteration in Finnish pegmatites. Geological Survey of Finland, Bulletin 368. 39 p.

Vesasalo, A. 1959. On the petalite occurrences of Tammela, SW-Finland. Bulletin de la Commission géologique de Finlande 184, 59-74. 